\title{
PENERAPAN METODE COOPERATIVE SCRIPT \\ DALAM MENINGKATKAN HASIL BELAJAR SISWA
}

\author{
Ferasiska Y. Hasim ${ }^{1}$ \& Irina Popoi $^{2}$ Ardiansyah $^{3}$ \\ Jurusan Pendidikan Ekonomi, Fakultas Ekonomi, Universitas Negeri Gorontalo \\ Feramat2210@gmail.com
}

\begin{abstract}
Abstrak
Ferasiska Y Hasim Nim 911415116 "Penerapan Metode Cooperative Script Dalam Meningkatkan Hasil Belajar Siswa". Program Studi S-1 Pendidikan Ekonomi, Jurusan Pendidikan Ekonomi, Fakultas Ekonomi, Universitas Negeri Gorontalo .Penelitian ini bertujuan untuk meningkatkan hasil belajar siswa pada mata pelajaran IPS Terpadu di SMP Negeri 1 Kabila Kabupaten Bone Bolango Provinsi Gorontalo dengan jumlah siswa 27 orang. Metode yang digunakan dalam Penelitian ini adalah penelitian tindakan kelas (PTK). Yang dilaksanakan dalam II siklus. Dari hasil penelitian pada pelaksanaan tindakan kelas ini, hasil pada siklus I 62,97\%, pada siklus II 81,49\%, sedangkan siswa yang belum tuntas diremedial kembali dengan penerapan metode Cooperative Script pada mata pelajaran IPS Terpadu kelas VIII-A. Dengan demikian dapat disimpulkan bahwa metode Cooperative Script secara signifikan dapat meningkatkan hasil belajar siswa kelas VIII-A Pada Mata Pelajaran Ips Terpadu.
\end{abstract}

Kata Kunci : Cooperative Script, Hasil Belajar Siswa 


\begin{abstract}
Ferasiska Y. Hasim ${ }^{1}$ \& Irina Popoi ${ }^{2}$ Ardiansyah $^{3}$

Department of Economic Education, Faculty of Economics, Gorontalo State University

Feramat2210@gmail.com
\end{abstract}

\begin{abstract}
Ferasiska Y Hasim Nim 911415116 "Application of Cooperative Script Learning Method in Improving Learning Outcomes ". Undergraduate Economic Education Study Program, Department of Economic Education, Faculty of Economics, Gorontalo State University The research aimed to improve student's learning outcomes at integrated social science subjek in SMP Negeri 1 Kabila of bone bolango District, Gorontalo Province. The methode applied in this research was classroom action research that was conducted in II cycles and involved 27 people. The finding of research found that result of this classroom action research in cycle I reached $62,97 \%$ then increased to $81,49 \%$ in cycle II meanwhile, students who were not completed would be remedied through the implementation of cooperative script method at integrated social Science subjek in grade VIII thus the students' learning outcomes Improved.
\end{abstract}

Keywords: Cooperative Script, Student Learning Outcomes 


\section{Pendahuluan}

Belajar dikatakan berhasil apabila mengalami perubahan secara positif. Jika proses belajar ini kemudian ditarik menjadi garis lurus maka bisa dikatakan belajar yang baik dan menyenangkan akan menghasilkan hasil yang baik pula. Dengan kata lain hasil belajar siswa akan meningkat atau lebih baik dari pada sebelumnya. Keberhasilan siswa dalam meraih hasil belajarnya tidak terlepas dari cara guru manajemen kelas atau mengusai strategi pembelajaran. Salah satunya dengan menggunakan metode yang bisa mengembangkan proses kemampuan berpikir peserta didik.

Hasil belajar dapat dikatakan sebagai kemampuan-kemampuan yang dimiliki siswa setelah ia menerima pengalaman belajar, hasil belajar ialah pencapaian yang diperoleh seseorang setelah mengikuti evalusi yang di tandai dengan nilai.

Metode adalah jalan yang ditempuh dalam rangka memberikan sebuah pemahaman terhadap murid tentang pelajaran yang merekapelajari. Metode sangat penting yang harus dimikili oleh seorang guru sebelum memasuki ruang belajar, dan harus dipakai olehseorang guru.

Metode sangat berpengaruh besar dalam pengajaran, dengan metode nilai bisa baik atau buruk, dengan metode pula pembelajaran bisa sukses atau gagal.

Metode yang digunakan dalam kegiatan pembelajaran masih menggunakan metode ceramah. Pembelajaran dengan menggunakan metode ceramah, hanya menekankan pada pencapian tujuan kurikulum dari pada mengembangkan kemampuan belaja siswa. Kondisi seperti ini tidakakan menumbuh kembangkan kemampuan dan aktivitas belajar siswa seperti yang diharapkan. Dalam proses pembelajaran guru bersifat aktif sedangkan anak itu bersifat pasif. Sehingga siswa lebih banyak menunggu sajian dari gurunya dari pada menemukan dan mencari sendiri pengetahuan, keterampilan atau sikap yang mereka perlukan.

Proses pembelajaran akan lebih hidup dan menjalin kerjasama dengan baik apabila anak dilibatkan secara langsung dalam proses pembelajaran, peran guru dalam kegiatan tersebut hanya membimbing serta mengarahkan anak dalam kegiatan pengajaran yang demikian, anak akan belajar dan menemukan sendiri pengetahuan yang dicapai, sehingga proses pengajaran akan lebih berhasil sesuai yang diharapkan

Berdasarkan observasi awal bahwa hasil belajar siswa pada mata pelajaran IPS Terpadu kelas VIII di SMP Negeri 1 Kabila masih rendah dan masih jauh dari yang diharapkan. Indikatornya antara lain adanya kecerendungan rendahnya ketekunan siswa dalam mengerjakan tugas, mudah putus asa dalam setiap menghadapi kesulitan pada pelajaran, 
kurang minatnya terhadap pelajaran, dalam menghadapi pelajaran sangat bergantung pada orang lain, dan memiliki pendirian yang berubah-ubah dalam mempertahankan pendapat.

Faktor yang diduga sebagai faktor penyebab rendahnya hasil belajar siswa pada mata pelajaran IPS terpadu antara lain adalah siswa kurang memahami materi yang diajarkan oleh guru dengan pembelajaran yang begitu monoton dan guru kurang paham dengan model yang digunakan pada saat proses belajar mengajar. Akibatnya hasil belajar siswa rendah atau belum mencapai target yang diinginkan dilihat dari jumlah siswa VIII-A IPS Terpadu yang berjumlah 27 orang siswa, terdapat 7 orang siswa atau 25,93\% siswa yang memenuhi kriteria ketuntasan dan 20 orang siswa atau 74,07\% siswa belum memenuhi kriteria ketuntasan. Berdasarkan KKM minimun $80 \%$ dari jumlah siswa harus tuntas belajar atau mendapatkan nilai hasil belajar minimum 75 .

Salah satu cara yang dapat dilakukan agar melibatkan siswa secara aktif dalam kegiatan pembelajaran, yaitu dengan menerapkan metode Cooperative Script dimana siswa bekerja berpasangan dan bergantian secara lisan. Metode Cooperative Script ini adalah metode sederhana yang dapat dipakai untuk mempraktekan sesuatu keterampilan atau prosedur dengan teman belajar. Tujuan adalah untuk menyakinkan masing-masing pasangan dapat melakukan keterampilan dengan benar. Materi-materi yang bersifat psikomotorik adalah meteri yang baik untuk diajarkan dengan strategi ini.

\section{Kajian Hipotesis Dan Hipotesis Tindakan}

\section{Hasil Belajar Siswa}

Hasil belajar merupakan hal yang berhubungan dengan kegiatan belajar karena kegiatan belajar merupakan proses sedangkan dalam hasil belajar adalah sebagai hasil yang dicapai seseorang setelah mengalami proses belajar dengan terlebih dahulu mengadakan evaluasi dari proses belajar yang di lakukan. Dimyati dan Mudjiono (2013:3) hasil belajar siswa adalah hasil dari suatu interaksi tindak belajar dan tindak mengajar. Dari sisi guru, tindak mengajar diakhiri dengan evaluasi hasil belajar. Dari sisi siswa, hasil belajar merupakan berakhirnya penggal dan puncak proses belajar. Menurut Sudjana (2009:22) hasil belajar siswa adalah kemampuan-kemampuan yang dimiliki siswa setelah ia menerima pengalaman belajarnya. Sedangkan Purwanto (2009:54) hasil belajar merupakan perubahan perilaku yang terjadi setelah mengikuti proses belajar mengajar sesuai dengan tujuan pendidikan. Sardiman (2007:15) hasil belajar siswa adalah hasil langsung berupa tingkah laku siswa setelah melalui proses belajar mengajar yang sesuai materi yang dipelajarinya. Menurut Hamalik (2008:155) hasil belajar tampak sebagai terjadinya perubahan tingkah laku pada diri siswa, yang dapat 
diamati dan dikukur dalam bentuk perubahan pengetahuan sikap dan keterampilan. Perubahan tersebut dapat diartikan terjadi peningkatan dan pengembangan yang lebih dibandingkan dengan sebelumnya, misalnya dari tidak tahu menjadi tahu, sikap kurang disiplin menjadi lebih disiplin dan sebagainya. Sedangkan Mulyasa (2008:25) hasil belajar merupakan prestasi belajar siswa secara keseluruhan yang menjadi indikator kompotensi dan derajat perubahan perilaku yang bersangkutan. Kompotensi yang harus dikuasai siswa perlu dinyatakan sedimikian rupa agar dapat nilai sebagai wujud hasil belajar siswa yang mengacu pada pengalaman langsung.

\section{Metode Cooperative Script}

Metode Cooperative Script ini adalah metode sederhana yang dapat dipakai untuk mempraktekkan suatu keterampilan atau produser dengan teman belajar. Dansereauet.al (1985:12) Cooperative Script adalah suatu cara bekerja sama dalam membuat naskah tulisan tangan dengan berpasangan dan bergantian secara lisan dalam mengintisarikan materi-materi yang dipelajari. Menurut Huda (2013:213) Cooperative Script adalah untuk membantu siswa berpikir secara sistematis dan berkonsentrasi pada mata pelajaran. Siswa juga dilatih untuk saling bekerja sama satu sama lain dalam suasana menyenangkan. Cooperative Script juga memungkinkan siswa untuk menemukan ide-ide pokok dari gagasan besar.

Lambiote dalam (Hidayat et.al 2017:563) metode pembelajaran Cooperative Script merupakan salah satu strategi pembelajaran di mana siswa bekerja secara berpasangan dan bergantian secara lisan dalam mengikhtisarkan materi yang dipelajari. Menurut A'la (2011:97) metode pembelajaran Cooperative Script di sebut juga Skrip kooperatif adalah metode belajar dimana siswa bekerja berpasangan dan secara lisan mengikhtisarkan bagianbagian dari materi yang dipelajarinya dalam ruangan kelas. Sedangkan Slavin dalam (Maksum et.al 2013:1074) Cooperative Script adalah metode pembelajaran dimana siswa berkerja berpasangan dan mengikhtisarkan bagian-bagian dari materi yang dipelajari.

\section{Langkah-Langkah Metode Cooperative Script}

Rifatun dalam (Suprijono 2010:126-127) Langkah-langkah pertama menerapkan Metode Cooperative Script pada proses pembelajaran sebagai berikut:

1. Guru membagi siswa untuk berpasangan,

2. Guru membagikan wacana/materi tiap siswa untuk dibaca dan membuat ringkasan,

3. Guru dan siswa menetapkan siapan yang pertama dan berperan sebagai pembicara dan siapa yang sebagai pendengar, 
4. Pembicara membacakan ringkasanhya selengkap mungkin, dengan memasukan ide-ide pokok dalam ringkasannya sementara pendengar,

5. Menyimak/mengoreksi/menunjukan ide-ide pokok yang kurang lengkap

6. Membantu mengingat/menghafal ide-ide pokok dengan menghubungkan materi sebelumnya atau dengan materi lainnya,

7. Bertukar peran, semula sebagai pembicara ditukar menjadi pendengar dan sebaliknya serta lakukan seperti diatas,

8. Kesimpulan siswa bersama-sama dengan guru, dan

9. Penutup.

\section{Metode Penelitian}

\section{Waktu dan Tempat Penelitian}

Penelitian ini dilaksanakan di Kelas VIII-A SMP Negeri 1 Kabila Kabupaten Bone Bolango Provinsi Gorontalo Lokasi tersebut pada beberapa alasan bahwa objek tersebut sesuai dengan tujuan penelitian, selain itu data yang digunakan sebagai bahan penelitian cukup memadai dan mudah memperolehnya, baik dari segi waktu, biaya dan tenaga yang diperlukan. Subjek dari penelitian adalah kelas VIII-A yang berjumlah 27 orang.

\section{Variabel Peneltian}

Secara umum terdapat 3 (tiga) variabel dalam penelitian ini yaitu variable input, variabel proses, dan variable output. Variabel input berupa siswa kelas VIII-A di SMP Negeri 1 Kabila. Khususnya kelas VIII yang berjumlah 27 orang siswa yang menjadi subjek penelitian, pada mata pelajaran IPS Terpadu, Variabel proses dalam penelitian ini adalah penerapan metode Cooperative Script pada mata pelajaran IPS Terpadu kelas VIII-A SMP Negeri 1 Kabila dalam kegiatan belajar mengajar selama penelitian berlangsung, Dan variabel output yang diharapkan adalah hasil belajar siswa kelas VIII-A SMP Negeri 1 Kabila khususnya untuk mata pelajaran IPS Terpadu akan mengalami peningkatan.

\section{Prosedur Penelitian}

Adapun alur penelitian ini mengacu pada modifikasi diagram oleh setiap siklus Kemmis dan Mc. Taggart dalam (Umar 2005:11) terdiri dari beberapa tahapan pelaksanaan yaitu: (1) Perencanaan, (2) Pelaksanaan, (3) Observasi serta, dan (4) Refleksi

\section{Teknik Analisis Data}

Analisis data dilaksanakan dengan menggunakan metode tindakan kelas pada setiap siklus pembelajaran. Data yang dianalisis meliputi observasi kegiatan guru dan aktifitas siswa serta data hasil belajar siswa. Dalam teknik analisis data yang digunakan dalam penelitian ini 
diuraikan sebagai berikut : 1) Data hasil pengamatan kegiatan guru diolah secara kuantitatif, 2) Pengumpulan data kegiatan siswa dilakukan secara individu dan kelompok, hasil ini dianalisis secara kuantitatif dengan menggunakan presentasi, dan 3) Untuk mengetahui hasil belajar siswa, maka peneliti menggunakan rumus:

Rata - rata kelas $=\frac{\text { Jumlah nilai seluruh siswa }}{\text { Jumlah siswa }}$

Rata - rata daya serap $=\frac{\text { Jumlah skor pencapaian }}{\text { Jumlah skor tetapx100 }}$

Presentase nilai 75 ke atas

$$
=\frac{\text { Jumlah siswa yang tuntas }}{\text { Jumlah seluruh siswax100 }}
$$

\section{Hasil Penelitian Dan Pembahasan}

\section{Hasil Penelitian}

Penelitian ini merupakan penelitian tindakan kelas yang menyajikan materi mengenai pelaku ekonomi dalam perekonomian dengan menerapkan metode pembelajaran Cooperative Script yang diajarkan kepada 27 orang siswa kelas VIII-A SMP Negeri 1 Kabila Kabupaten Bone Bolango Provinsi Gorontalo, sebanyak 2 siklus yaitu siklus I dan siklus II. Pelaksanaan siklus I dan siklus IIini masing-masing dilaksanakan setelah hasil yang diperoleh dari pembelajaran siklus I belum mencapai indikator kinerja yang ditetapkan maka dilaksanakan siklus II untuk mencapai indikator yang telah ditetapkan.

\section{Observasi Awal}

Pada observasi awal yang dilakukan peneliti di kelas VIII-A SMP Negeri 1 Kabila ditemui bahwa ternyata banyak siswa yang tidak mencapai hasil belajar di bawah KKM yaitu 75. Adapun hasil belajar siswa pada observasi awal dapat dilihat dalam tabel berikut:

\section{Tabel 4.1 Data Hasil Belajar Siswa Pada Observasi Awal}

\begin{tabular}{|cccc}
\hline $\begin{array}{c}\text { Jumlah } \\
\text { Siswa }\end{array}$ & KKM & Presentase & Ket \\
\hline 7 & $>75$ & $\mathbf{2 5 , 9 3 \%}$ & Tuntas \\
\hline 20 & $<75$ & $\mathbf{7 4 , 0 7 \%}$ & Tidak Tuntas \\
\hline
\end{tabular}

Berdasarkan tabel, jelas terlihat bahwa jumlah siswa yang tuntas dengan nilai 75 ke atas sebanyak 7 orang siswa dengan presentase $25,93 \%$, sedangkan jumlah siswa yang belum 
tuntas atau memperoleh nilai 75 ke bawah sebanyak 20 orang siswa dengan presentase $74,07 \%$, disebabkan oleh kurangnya keaktifan siswa dalam proses belajar berlangsung, hal ini dipengaruhi oleh penggunanaan variasi atau metode mengajar kurang diterapkan sehingga menyebabkan siswa menjadi malas menerima pelajaran yang diajarkan guru.

\section{Pembahasan}

Penelitian tindakan kelas pada siswa kelas VIII-A SMP Negeri 1 Kabila Kabupaten Bone Bolango Provinsi Gorontalo bertujuan untuk meningkat hasil belajar siswa Pada Mata Pelajaran IPS Terpadu Khususnya pada materi Pelaku ekonomi dalam perekonomian dengan menerapkan metode Cooperative Script dengan indikator yang ingin dicapai $80 \%$. Siswa yang menjadi objek penelitian 27 siswa dan dikatakan tuntas apabila memperoleh nilai di atas 75. Penelitian ini menggunakan metode pembelajaran Cooperative Script yaitu suatu cara bekerja sama dalam membuat naskah tulisan tangan secara berpasangan dan bergantian dalam kontak lisan dalam mengintisarikan materi-materi yang dipelajari. Hasil penelitian ini dilakasanakan dalam 2 siklus, pada siklus 1 mencapai 62,97\% tetapi peningkatan ini masih belum mencapai indikator yang telah ditetapkan yaitu $80 \%$. Untuk itu dilanjutkan ke siklus II. Tapi sebelumnya diadakan refleksi dengan melihat kelemahan-kelemahan yang ada pada disiklus I. Pada siklus II meningkat menjadi 81,49\%, olehnya ada peningkatan $18,53 \%$. Peneiltian ini relevan dari Ismi Fauziah (2013) yang berjudul penerapan metode Cooperative Script untuk meningkatkan hasil belajar siswa kelas VII pada mata pelajaran IPS Terpadu di MTS Negeri Ciledug Kabupaten Cirebon. Peneltian yang digunakan yaitu penelitian tindakan kelas (PTK) yang dilaksanakan dalam dua silkus, yang masing-masing silkus terdiri dari tahap perencanaan tindakan, observasi dan refleksi. Hal ini dapat dibuktikan dengan hasill belajar siswa yang meningkat dari setiap siklusnya, perolehan pada prasiklus jumlah siswa yang mencapai kkm 7 siswa dengan nilai rata-rata 45,9 dan presentase kekuntasan 15,2\%. Pada silkus I jumlah siswa yang mencapai kkm 10 siswa dengan nilai rata-rata 52,2 dan presentase kekuntasan siswa $21,7 \%$, pada siklus II siswa yang mencapai kkm 21 siswa dengan nilai ratarata 63,9 dan presentase ketuntasannya 45,6\% dan pada siklus 3 siswa yang mencapai kkm 46 siswa dengan nilai rata-rata 75 dan presentase ketuntasannya 100\%. dan perbedaanya terletak pada materi yang diajarkan Dari uraian diatas, dapat disimpulkan bahwa hipotesis yang dirumuskan dalam penelitian tindakan kelas ini adalah dengan menerapkan metode Cooperative Script pada mata pelajaran IPS Terpadu di kelas VIII-A SMP Negeri 1 Kabila Kabupaten Bone Bolango Provinsi Gorontalo dapat meningkatkan hasil belajar siswa. 


\section{Simpulan}

Berdasarkan hasil penelitian dan pembahasan maka dikemukakan kesimpulan sebagai berikut : Penerapan metode cooperative script dapat meningkatkan hasil belajar siswa kelas VIII-A, yang hal ini dibuktikan hasil belajar siswa memperoleh nilai kriteria ketuntasan minimun (KKM) 75 dari observasi awal 25,93\% menjadi 62,67\% pada siklus I dan meningkat lagi menjadi $81,49 \%$ pada siklus II.

\section{REFERENSI}

A’la, Miftahul. 2011. Quantum Teaching. Yogyakarta : Diva Press.

Dimyati Dan Mudjiono. 2013. Belajar Dan Pembelajaran. Jakarta: PT. Rineka Cipta.

Dansereau. et.al. 1985. Strategi Pembelajaran Penelitian. Di JW Segal. SF Chipman \& R. Glaser (Eds). Keterempilan Berpikir Dan Belajar. Vol 1. Mengaitkan Instruksi Dengan Penelitian. Hillsdale NJ: Erlbaum. Digilib . Uinsby. ac. Id.

Hamalik, Oemar. 2008. Perencanaan Pengajaran Berdasarkan Pendekatan Sistem. Jakarta: PT Bumi Aksara.

Huda, Miftahul. 2013. Model-Model Pengajaran Dan Pembelajaran. Yogyakarta: Pustaka Pelajar

Hidayat, Irwan. 2017. Penerapan Model Pembelajaran Cooperative Script Berbantuan Mind Map Untuk Meningkatkan Keterampilan Berpikir Kritis Dan Hasil Belajar Ips Siswa Kelas V. Jurnal Pendidikan, Vol. 2, No. 4, Hal 562-568.

Istarani. 2011. Metode Pembelajaran Inovatif. Jakarta: Buku Iranda.

Majid, Abdul. 2013. Strategi Pembelajaran. Bandung: PT. Remaja Rosdakarya.

Mulyasa. 2008. Menjadi Guru Profesional Menciptakan Pembelajaran Kreatif dan Menyenangkan. Bandung : PT. Remaja Rosdakarya.

Mulyasa. 2008. Implementasi Kurikulum Tingkat Satuan Pendidikan: Kemandirian Guru Dan Kepala Sekolah. Jakarta: PT Bumi Aksara.

Maksum, Amir et.al. 2013. Model Cooperative Script Berpendekatan Scence, Environment, Technology, And Society (Sets). Jurnal Inovasi Pendidikan Kimia, Vol 7, No. 1, Hlm 1072-1082.

Purwanto. 2009. Evaluasi Hasil Belajar. Yogyakarta: Pustaka Pelajar 
Sudjana, Nana. 2009. Penilaian Hasil Proses Belajar Mengajar. Bandung: PT. Remaja Rosdakarya.

Slameto. 2010. Belajar Dan Faktor-Faktor Yang Mempengaruhinya. Jakarta: Rineka Cipta.

Sardiman. 2007. Interaksi Dan Motivasi Belajar Mengajar. Bandung: Rajawali Pers.

Samsuri. 1991. Belajar Dan Faktor-Faktor Yang Mempengaruhinya. Jakarta: Rineka Cipta

Suprijono. 2010. Cooperative Learning Teori dan Aplikasi PAIKEM. Yogyakarta: Pustaka Pelajar. 